\title{
The hydraulic management of the Barra Bonita reservoir (SP, Brazil) as a factor influencing the temporal succession of its fish community
}

\author{
Petesse ML. ${ }^{\mathrm{a} *}$, Petrere Jr., M. ${ }^{\mathrm{a} *}$ and Spigolon RJ. ${ }^{\mathrm{b} *}$ \\ aDepartamento de Ecologia, Universidade Estadual Paulista - UNESP, \\ CP 199, CEP 13506-900, Rio Claro, SP, Brazil \\ ${ }^{\text {b} A g e ̂ n c i a ~ P a u l i s t a ~ d e ~ T e c n o l o g i a ~ e ~ A g r o n e g o ́ c i o s ~-~ A P T A, ~}$ \\ Avenida Pedro Ometto, 874, CEP 17340-000, Barra Bonita, SP, Brazil \\ *e-mail: mlpetesse@gmail.com, mpetrere@ rc.unesp.br, spigolonjr@ig.com.br \\ Received August 4, 2005 - Accepted December 2, 2005 - Distributed August 31, 2007
}

(With 8 figures)

\begin{abstract}
The temporal succession of fish communities allows evaluating the environmental conditions and the adaptation capacity of the fish species to anthropogenic stress in reservoirs. The fish community at Barra Bonita reservoir was sampled in two different periods of the year (dry and rainy) and in three different areas of the reservoir (fluvial, transition, and lentic). The species list was compared to another four lists, trying to detect the transformations of the fish community for the last 15 years. In order to evaluate the adaptation of the present fish community to the hydraulic management of reservoir, the trophic and reproductive structures were studied. Temporal succession analysis shows little change in fish richness of the communities. The number of fish species varies between 23 and 39 for a total of 68 registered species. From this, 27 can be considered constant, 14 accessory and 27 accidental; the main differences observed were for Anostomidae, Loricariidae and Characidae families. In relation to the hydraulic management, we found a fish community stabilized and adapted to environmental stress. This is characterized by the dominance of small-sized fish species of opportunistic diet and high reproductive compensation (r-strategists). The overlap of biological cycles of the most abundant species with the reservoir level fluctuations points to the period from September to March-April as critical for reproductive success and only the species with partial reproductive strategy or parental care are best succeeded. These results, interpreted in the context of the reservoir aging process, indicate that Barra Bonita reservoir is entering a transition phase, between the colonization and aging stages.
\end{abstract}

Keywords: Barra Bonita reservoir, fish assemblage, temporal succession, trophic and reproductive structure.

\section{Gestão hidráulica da represa de Barra Bonita - SP, Brasil, como fator de controle da sucessão temporal de sua comunidade de peixes}

A sucessão temporal das comunidades de peixes permite avaliar o estado do ambiente e a capacidade de adaptação das espécies às perturbações. Com este propósito, a comunidade de peixes da represa de Barra Bonita foi amostrada em duas épocas do ano (seca e chuvosa) em três zonas diferentes do reservatório: fluvial, transição e lêntica. A lista das espécies foi comparada com outras quatro, referentes a coletas anteriores, visando detectar as variações ocorridas na composição ictiofaunística da represa, ao longo dos últimos 15 anos. Para avaliar a adaptação da comunidade atual à variabilidade ambiental, a estrutura trófica e reprodutiva foi analisada junto com a gestão hidráulica da represa. O número total de registros por autores varia entre 23 e 39, num total registrado de 68 espécies. Destas, 27 podem ser consideradas constantes, 14 acessórias e 27 acidentais. As principais diferenças observadas estão nas famílias: Anostomidae, Loricariidae e Characidae. Em relação à gestão hidráulica, os resultados mostram uma comunidade estabilizada e adaptada às flutuações ambientais, dominada por espécies de pequeno porte, amplo espectro alimentar e alta compensação reprodutiva (r-estrategistas). A sobreposição dos ciclos biológicos das espécies mais abundantes com as fases de enchente e esvaziamento da represa indica o período de setembro a março-abril como crítico para o sucesso reprodutivo. Estes resultados, interpretados no contexto do processo de velhice do ambiente, indicam que a represa de Barra Bonita está entrando numa fase de transição entre a de colonização e velhice.

Palavras-chave: represa de Barra Bonita, ictiofauna, transformação da comunidade, estrutura trófica e reprodutiva. 


\section{Introduction}

Several studies deal with the effects of the impoundment on the ichthyofauna (Branco and Rocha, 1977; Castro and Arcifa, 1987; Fernando and Holcik, 1991; Woynarovich, 1991; Granado-Lorencio, 1991, 1992; Agostinho et al., 1994; Agostinho, 1995; Agostinho et al., 1999; Craig, 2000; Larinier, 2000). Nevertheless, the studies dealing with community changes in time, related to the hydraulic management of the reservoir are rare. Britski (1994) claims that dam-building provokes serious changes to the environment, and relevant loss of biodiversity with unpredictable consequences in the medium to long term. Therefore, it is necessary to carry out a previous species inventory aiming to understand and reduce the environmental impact. Many studies show how fishes can be seen as environmental indicators (Karr, 1981; Fausch et al., 1990; Jennings et al., 1995) and the interpretation of the temporal changes in terms of species composition, abundance, trophic and reproductive strategies allows one to evaluate the environmental quality where they live. The reservoir is an artificial ecosystem where the change of the hydraulic cycle, the water level fluctuation and the non-predictable events of pulses, determine a continuous reorganization of the living communities (Júlio et al., 1997; Magela Thomaz et al., 1997; Bergkamp et al., 2000). This does not allow an evolution according to equilibrated patterns compromising ecosystem productivity (Tundisi et al., 1999).

The present paper describes the temporal changes in the fish community of Barra Bonita Reservoir and evaluates the effects of hydraulic management on feeding and reproduction of the present fish community.

\section{Materials and Methods}

\subsection{Study area}

Barra Bonita Reservoir is located in the Tietê River basin $\left(20^{\circ} 31^{\prime} \mathrm{S}\right.$ and $\left.48^{\circ} 32^{\prime} \mathrm{W}\right)$, in the proximity of Barra Bonita and Iguaraçu do Tietê cities (SP). The reservoir drains $44 \%$ of the $71,988 \mathrm{~km}^{2}$ of the Tietê river basin. In this portion are located the most intense industrial activities of the region and 17 million people are concentrated in the metropolitan area of São Paulo city. The absence of adequate treatment of industrial and domestic sewage causes relevant problems in the water quality of the river (Barrella and Petrere, 2003). Only in the upper stretch of the Barra Bonita Reservoir, the river recovers a little and presents acceptable conditions of water quality.

Barra Bonita Reservoir was impounded between 1962 and 1964. According to the limnological aspects, it is classified as polymictic and eutrophic (Tundisi and Matsumura-Tundisi, 1990; Barbosa et al., 1999). The fish production, nevertheless, is higher than that of the downstream reservoirs, because important reproductive areas are still located in the two main tributaries (Tietê and Piracicaba rivers) (CESP, 1996; Okada et al. 2003).

The primary purpose of the reservoir is the generation of hydropower. Recreational and small-scale professional fishing and navigation are secondary activities. Its area is $310 \mathrm{~km}^{2}$ at the maximum water level of $451.5 \mathrm{~m}$, and the average depth is of $10.1 \mathrm{~m}$. On the longitudinal section,

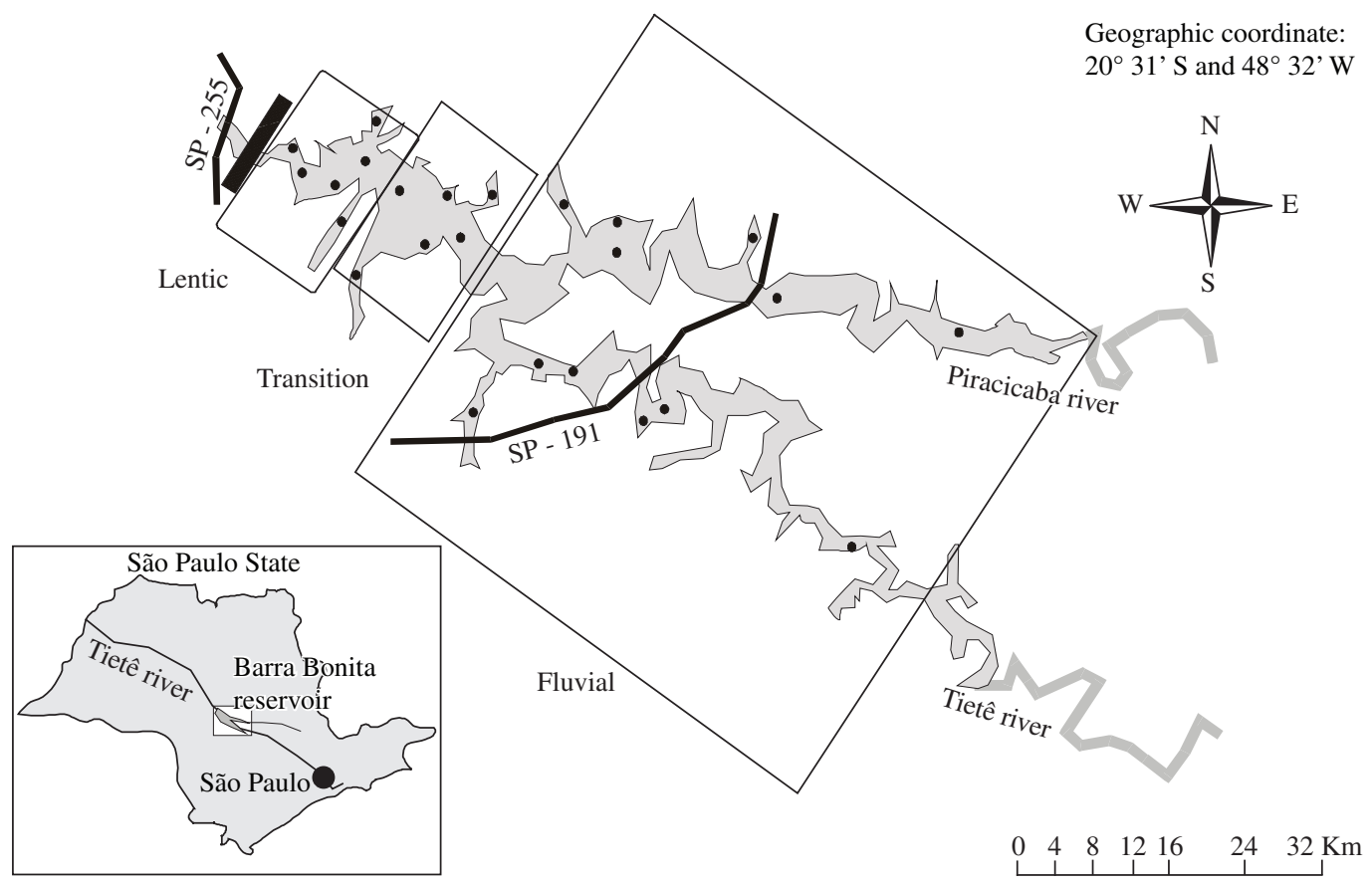

Figure 1. Barra Bonita reservoir and the sampling sites. 
three distinct zones can be recognized, as defined by McDonough and Hickman (1999): fluvial, transition and lentic, (Figure 1). In each of these zones, six sampling sites were selected in three different habitat types: mouth of tributaries, littoral, and central body of the reservoir. Considering that Barra Bonita Reservoir has two main tributaries (Tietê and Piracicaba rivers), we sampled two fluvial zones for a total of 24 sampling points. They were sampled in two different periods of the year: dry (winter), August/ September 2003, and rainy (summer), February 2004. The sampling was standardized using 10 gillnets with mesh size ranging from 3 to $12 \mathrm{~cm}$ between opposite knots.

The landscape surrounding Barra Bonita Reservoir has a gentle slope. Considering the lack of a bathymetric map, visual observation and profundity measures were taken in all sampling stations aiming to evaluate the biotope sensitivity to bottom exposure in relation to water level fluctuation.

\subsection{Dajoz constancy index}

The present fish list was compared with those of Torloni et al. (1993), Castro (1997), Barrela and Petrere (2003), and Freitas (1999) through the Dajoz constancy index (Dajoz, 1973). The sampling method was the same for all the authors and involved similar effort, with the exception of Torloni et al. (1993), who only considered the species caught by professional fishers from 1989-1991. The constancy index is the percentage ratio between the number of samples in which a species is present and the total of samples. It is defined as: constant species, the ones present in more than $50 \%$ of the samples; accessory species, present between $25 \%$ and $50 \%$ of the samples; accidental species, present in less than $25 \%$ of the samples.

\subsection{Cluster analysis}

In order to evaluate the similarity between the five lists of species, a cluster analysis was performed. The original matrix of presence/absence was formed by 5 sample (lists) and 68 species. The clustering method was the UPGMA (Unweighted Pair Group Method Average), and the Jaccard index was the measure of distance selected. To evaluate the distortion caused by the clustering method, the cophenetic coefficient was calculated by the correlation of original and cophenetic matrices. A value higher than 0.75 is considered a good representation of the original data as suggested by McGarigal et al. (2000).

\subsection{Hydraulic management}

In order to characterize the reservoir hydraulic management we considered: the water retention time (RT, days), the yearly maximum range of water level (YMR, m) from 1969 to 2002 and the daily reservoir water level from March 1968 to December 2002. The data source of historical data series was the agency of electric plant management (AES- Tietê, www.aestiete. com.br).
The Durbin-Watson Index was used in order to test the autocorrelation due to the use of time as an independent variate in the regression between the retention time (response variate) and year (independent variate) (Chatterjee and Price,1991; Draper and Smith, 1966).

The Durbin-Watson Index is given by the $d$ statistic, defined as:

$d=\frac{\sum_{2}^{n}\left(e_{t}-e_{t-1}\right)^{2}}{\sum_{1}^{n} e_{t}^{2}}$

where: $e_{t}=$ residual in time $t ; e_{t-1}$ the residual in time $t-1$. The relation between $d$ and the correlation coefficient $r$ is: $d=2(r-1)$ showing that $d$ can range between 0 e 4 . Values of $d$ close to 2 indicate absence of autocorrelation $(\rho=0)$ (Chatterjee and Price, 1991).

\subsection{Species richness - jackknife estimate}

To estimate the species richness in Barra Bonita Reservoir, the jackknife method was used. This is a nonparametric estimate, based on the frequency observed of rare species in the community (Krebs, 1998). The jackknife estimate is given by:

$\hat{S}=s+\left(\frac{n-1}{n}\right) * k$

where: $\hat{\mathrm{S}}=$ jackknife estimator of species richness; $s=$ total number of species in $n$ samples; $n=$ total number of samples; $k=$ number of unique species, where a unique species is the one that occurs in a single sample.

The analysis was performed by the jackknife routine, available in Krebs (1998). In order to calculate confidence limits, the jackknife variance was calculated as:

$$
\operatorname{var}(\hat{S})=\left(\frac{n-1}{n}\right) *\left[\sum_{j=1}^{s}\left(j^{2} f_{j}\right)-\frac{k^{2}}{n}\right]
$$

where: $\operatorname{Var}(\hat{S})=$ Jackknife's variance of richness of species; $f_{j}=$ number of sample with $j$ unique species $(j=1,2,3 \ldots . ., s) ; k=$ number of unique species; $n=$ total number of samples.

\subsection{The trophic structure}

This analysis is considered important as the changes in the environment or in the water quality may affect food availability and may cause changes in the fish community (Araújo, 1998). The adopted categories were (LoweMcConnel, 1999; Hahn et al., 1997; Celi-Fedatto-Abelha et al., 2001): omnivorous, herbivorous, iliophagous, detritivorous, invertivores, insenctivorous, planktivorous and carnivorous. The attribution of each trophic category was based on a bibliographical survey taking into account the dominant items of each species diet.

\subsection{The reproductive structure}

We considered the following aspects: type of spawning, reproductive period, reproductive strategy (i.e. migration and parental care) and species resilience, resulting from a bibliographical survey (www.fishbase.org as of December 2004; Nakatani et 
al, 2001; Santos, 1980; Vazzoler and Menezes, 1992; Vazzoler et al, 1997; Braga and Gennari-Filho 1991; Braga, 1997, 1999; Gennari-Filho and Braga, 1996). In the case of resilience, the informative source was the archive Fishbase (www.fishbase.org, as of 12/2004), based on the International Centre for Living Aquatic Resource Management (ICLARM - Manila, Philippines). According to Musick (1999), four resilience categories are considered: very low (population doubles in more than 14 years); low (population doubles in 4.5-14 years); medium (population doubles in 1.4-4.4 years); and high (population doubles before 13 months). These categories are based on some population parameters such as: $r_{m}$ (intrinsic rate of population growth, year-1), K (von Bertalanffy growth coefficient, year ${ }^{-1}$ ), $t_{\text {max }}$ (maximum age, years), $\mathrm{t}_{\mathrm{m}}$ (age at first maturity, years) and fecundity (number of eggs). The species classification in relation to its reproductive habits follows Vazzoler and Menezes (1992) that distinguish: migratory species, non-migratory species without parental care, and non-migratory species with parental care.

\section{Results}

\subsection{Fish community modifications}

Table 1 shows a list of species that have been recorded in Barra Bonita Reservoir since 1989. Seventeen families belonging to five orders (Characiformes, Cypriniformes, Siluriformes, Gymnotiformes and Perciformes), in a total of 68 species, were listed. The number of species varies between 23 and 39; in general, a high agreement among the five lists (Figure 2) can be noted, where only Freitas (1999) lies in a different cluster. The cophenetic correlation coefficient of $r_{c}=0.77$ means that the dendrogram is a good representation of the original data matrix. Twenty seven species presented the Dajoz constancy index higher than $50 \%$, and, therefore belong to the group of constant species in Barra Bonita Reservoir. In this group, three species (Callichthys callichthys, Leporinus friderici and Iheringichthys labrosus) were not recorded in the samples of the present work. The group of accessory species is formed of 14 fishes, including migratory species with a low rate of capture. Ten species of this group, mainly Anostomidae did not occur in our samples. The last group is formed of 27 accidental species, which include rare, difficult to capture, of recent introduction (e.g., Metynnis maculatus and Satanoperca jurupari) or fish with doubtful taxonomic classification. Seven species of this group occurred in our samplings (Hoplosternum littorale, Hyphessobrycon eques, Liposarcus anisitsi, Metynnis maculatus, Satanoperca jurupari, Schizodon fasciatus, Serrasalmus maculatus).

Not considering the Torloni et al. (1993) list, which results from professional fishing, a higher disagreement was detected among Anostomidae, Loricariidae and Characidae (Table 1). In Anostomidae, we did not collect seven species, principally the ones of difficult taxonomic identification, with herbivorous or omnivorous feeding habits and migratory behavior (Leporellus striatus, Leporellus vittatus, Leporinus friderici, Leporinus octofasciatus, Leporinus cf. paranensis, Schizodon altiparanae and Schizodon borelli) (Reis et al., 2003). In Loricariidae, the absence of five species belonging to Hypostomus (4) and Rhinolepis (1) was observed. In Characidae an increasing number of species was observed and the occurrence of three species never registered in the previous samplings (Hyphessobrycon eques, Metynnis maculatus and Serrasalmus maculatus). In relation to the other species, we observed that Callichthydae is represented by Callychthys callychthys in Castro (1997), Barrella and Petrere (2003) and Freitas (1999) and by Hoplostermun littorale in our samples; Iheringichthys

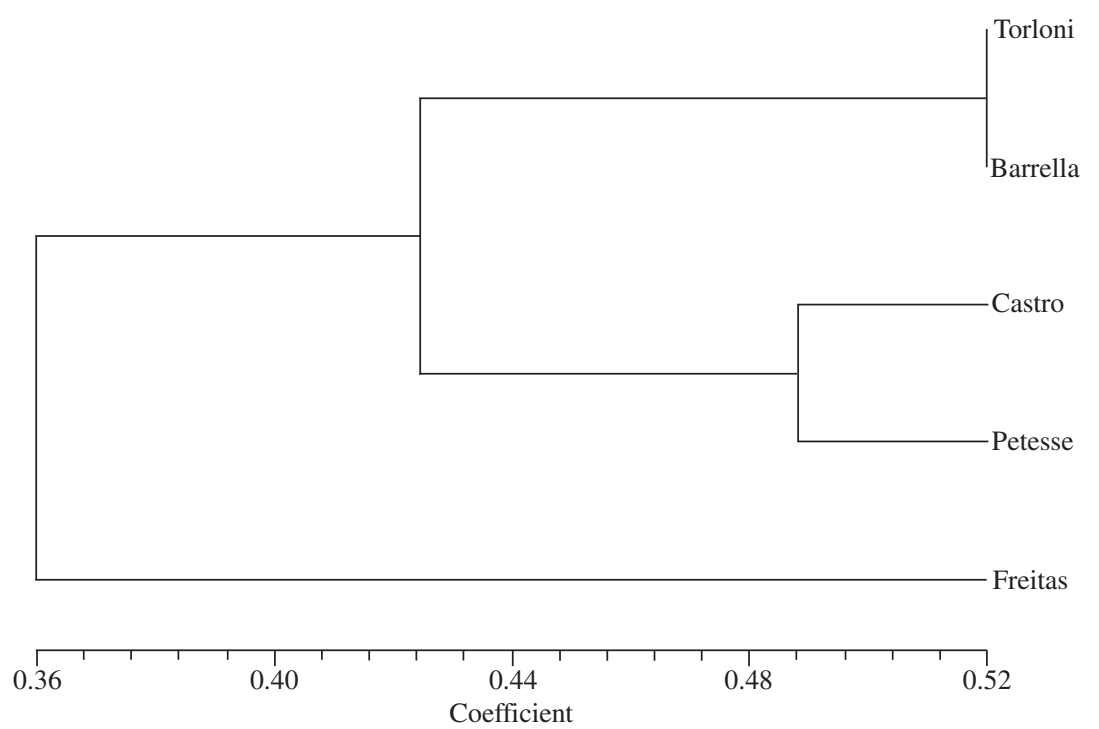

Figure 2. Cluster analyses comparing the similarity of lists of species registered in the Barra Bonita Reservoir. Cophenetic correlation coefficient $r_{c}=0.77$. 
Table 1. Fish species registered in Barra Bonita Reservoir in five samplings from 1989-2004 (DCI = Dajoz constancy index).

\begin{tabular}{|c|c|c|c|c|c|c|c|}
\hline \multirow[t]{2}{*}{ Species } & \multirow[t]{2}{*}{ Family } & \multicolumn{5}{|c|}{ Sampling period } & \multirow[t]{2}{*}{ DCI } \\
\hline & & 89-91(1) & $92-93(2)$ & 94-95 (3) & $03(4)$ & 03-04 (5) & \\
\hline Steindachnerina insculpta & Curimatidae & $\mathrm{x}$ & $\mathrm{x}$ & $\mathrm{x}$ & $\mathrm{x}$ & $\mathrm{x}$ & 100 \\
\hline Serrasalmus spilopleura & Characidae & $\mathrm{x}$ & $\mathrm{x}$ & $\mathrm{x}$ & $\mathrm{x}$ & $\mathrm{x}$ & 100 \\
\hline Schizodon nasutus & Anostomidae & $\mathrm{x}$ & $\mathrm{x}$ & $\mathrm{x}$ & $\mathrm{x}$ & $\mathrm{x}$ & 100 \\
\hline Prochilodus lineatus & Prochilodontidae & $\mathrm{x}$ & $\mathrm{x}$ & $\mathrm{x}$ & $\mathrm{x}$ & $\mathrm{x}$ & 100 \\
\hline Plagioscion squamosissimus & Scianidae & $\mathrm{x}$ & $\mathrm{x}$ & $\mathrm{x}$ & $\mathrm{x}$ & $\mathrm{x}$ & 100 \\
\hline Pimelodus maculates & Pimelodidae & $\mathrm{x}$ & $\mathrm{x}$ & $\mathrm{x}$ & $\mathrm{x}$ & $\mathrm{x}$ & 100 \\
\hline Hoplias malabaricus & Erithrynidae & $\mathrm{x}$ & $\mathrm{x}$ & $\mathrm{x}$ & $\mathrm{x}$ & $\mathrm{x}$ & 100 \\
\hline Cyphocharax nagelii & Curimatidae & $\mathrm{x}$ & $\mathrm{x}$ & $\mathrm{x}$ & $\mathrm{x}$ & $\mathrm{x}$ & 100 \\
\hline Cyphocharax modestus & Curimatidae & $\mathrm{x}$ & $\mathrm{x}$ & $\mathrm{x}$ & $\mathrm{x}$ & $\mathrm{x}$ & 100 \\
\hline Astyanax bimaculatus* & Characidae & $\mathrm{x}$ & $\mathrm{x}$ & $\mathrm{x}$ & $\mathrm{x}$ & $\mathrm{x}$ & 100 \\
\hline Geophagus brasiliensis & Cichlidae & & $\mathrm{x}$ & $\mathrm{x}$ & $\mathrm{x}$ & $\mathrm{x}$ & 80 \\
\hline Triportheus sp. & Characidae & $\mathrm{x}$ & $\mathrm{x}$ & $\mathrm{x}$ & & $\mathrm{x}$ & 80 \\
\hline Leporinus lacustris & Anostomidae & $\mathrm{x}$ & $\mathrm{x}$ & $\mathrm{x}$ & & $\mathrm{x}$ & 80 \\
\hline Astyanax schubarti & Characidae & $\mathrm{x}$ & $\mathrm{x}$ & $\mathrm{x}$ & & $\mathrm{x}$ & 80 \\
\hline Apareidon piracicabae & Parodontidae & $\mathrm{x}$ & $\mathrm{x}$ & $\mathrm{x}$ & & $\mathrm{x}$ & 80 \\
\hline Acestrorhynchus lacustris & Acestrorhynchidae & $\mathrm{x}$ & $\mathrm{x}$ & $\mathrm{x}$ & & $\mathrm{x}$ & 80 \\
\hline Moenkhausia intermedia & Characidae & & $\mathrm{x}$ & $\mathrm{x}$ & $\mathrm{x}$ & $\mathrm{x}$ & 80 \\
\hline Leporinus obtusidens & Anostomidae & $\mathrm{x}$ & & $\mathrm{x}$ & $\mathrm{x}$ & $\mathrm{x}$ & 80 \\
\hline Iheringichthys labrosus & Pimelodidae & $\mathrm{x}$ & $\mathrm{x}$ & $\mathrm{x}$ & $\mathrm{x}$ & & 80 \\
\hline Callichthys callichthys & Callichthyidae & $\mathrm{x}$ & $\mathrm{x}$ & $\mathrm{x}$ & $\mathrm{x}$ & & 80 \\
\hline Rhamdia sp. & Heptapteridae & $\mathrm{x}$ & $\mathrm{x}$ & & & $\mathrm{x}$ & 60 \\
\hline Gymnotus carapo & Gymnotidae & & $\mathrm{x}$ & $\mathrm{x}$ & & $\mathrm{x}$ & 60 \\
\hline Astyanax fasciatus & Characidae & & $\mathrm{x}$ & $\mathrm{x}$ & & $\mathrm{x}$ & 60 \\
\hline Leporinus friderici & Anostomidae & $\mathrm{x}$ & $\mathrm{x}$ & $\mathrm{x}$ & & & 60 \\
\hline Salminus hilari & Characidae & & $\mathrm{x}$ & & $\mathrm{x}$ & $\mathrm{x}$ & 60 \\
\hline Hypostomus ancistroides & Loricariidae & & & $\mathrm{x}$ & $\mathrm{x}$ & $\mathrm{x}$ & 60 \\
\hline Crenicichla sp. & Cichlidae & $\mathrm{x}$ & $\mathrm{x}$ & & & $\mathrm{x}$ & 60 \\
\hline Pimelodella sp. & Heptapteridae & $\mathrm{x}$ & & & & $\mathrm{x}$ & 40 \\
\hline Piaractus mesopotamicus & Characidae & $\mathrm{x}$ & & & & $\mathrm{x}$ & 40 \\
\hline Oreochromys niloticus & Cichlidae & & & & $\mathrm{x}$ & $\mathrm{x}$ & 40 \\
\hline Schizodon intermedius & Anostomidae & & $\mathrm{x}$ & & & $\mathrm{x}$ & 40 \\
\hline Hypostomus strigaticeps & Loricariidae & & & $\mathrm{x}$ & $\mathrm{x}$ & & 40 \\
\hline Cichla sp. & Cichlidae & $\mathrm{x}$ & & & $\mathrm{x}$ & & 40 \\
\hline Salminus maxillosus & Characidae & $\mathrm{x}$ & & $\mathrm{x}$ & & & 40 \\
\hline Rhinolepis strigosa & Loricariidae & $\mathrm{x}$ & & $\mathrm{x}$ & & & 40 \\
\hline Leporinus octofasciatus & Anostomidae & $\mathrm{x}$ & & $\mathrm{x}$ & & & 40 \\
\hline Leporinus cf.paranensis & Anostomidae & $\mathrm{x}$ & & $\mathrm{x}$ & & & 40 \\
\hline Leporellus striatus & Anostomidae & $\mathrm{x}$ & & $\mathrm{x}$ & & & 40 \\
\hline Characidium fasciatus & Characidae & $\mathrm{x}$ & & $\mathrm{x}$ & & & 40 \\
\hline Leporinus sp. & Anostomidae & & $\mathrm{x}$ & $\mathrm{x}$ & & & 40 \\
\hline Galeocharax knerii & Characidae & $\mathrm{x}$ & $\mathrm{x}$ & & & & 40 \\
\hline Satanoperca jurupari & Cichlidae & & & & & $\mathrm{x}$ & 20 \\
\hline Serrasalmus maculates & Characidae & & & & & $\mathrm{x}$ & 20 \\
\hline Schizodon fasciatus & Anostomidae & & & & & $\mathrm{x}$ & 20 \\
\hline Metynnis maculates & Characidae & & & & & $\mathrm{x}$ & 20 \\
\hline Liposarcus anisitsi & Loricariidae & & & & & $\mathrm{x}$ & 20 \\
\hline Hyphessobrycon eques & Characidae & & & & & $\mathrm{x}$ & 20 \\
\hline Hoplosternum littorale & Callichthyidae & & & & & $\mathrm{x}$ & 20 \\
\hline Schizodon borelli & Anostomidae & & & & $\mathrm{x}$ & & 20 \\
\hline
\end{tabular}


Table 1. Continued...

\begin{tabular}{|c|c|c|c|c|c|c|c|}
\hline \multirow[t]{2}{*}{ Species } & \multirow[t]{2}{*}{ Family } & \multicolumn{5}{|c|}{ Sampling period } & \multirow[t]{2}{*}{$\mathrm{DCl}$} \\
\hline & & 89-91(1) & $92-93(2)$ & 94-95 (3) & $03(4)$ & $03-04(5)$ & \\
\hline Hoplias lacerdae & Erithrynidae & & & & $\mathrm{x}$ & & 20 \\
\hline Sternopygus macrurus & Sternopygidae & & & & $\mathrm{x}$ & & 20 \\
\hline Roeboides paranensis & Characidae & & & $\mathrm{x}$ & & & 20 \\
\hline Geophagus sp. & Cichlidae & & & $\mathrm{x}$ & & & 20 \\
\hline Eigenmannia sp. & Sternopygidae & & $\mathrm{x}$ & & & & 20 \\
\hline Schizodon altiparanae & Anostomidae & & $\mathrm{x}$ & & & & 20 \\
\hline Oligosarcus pintoi & Acestrorhynchidae & & $\mathrm{x}$ & & & & 20 \\
\hline Hypostomus variipictus & Loricariidae & & $\mathrm{x}$ & & & & 20 \\
\hline Hypostomus tietensis & Loricariidae & & $\mathrm{x}$ & & & & 20 \\
\hline Hypostomus sp. & Loricariidae & & $\mathrm{x}$ & & & & 20 \\
\hline Apareidon affinis & Parodontidae & & $\mathrm{x}$ & & & & 20 \\
\hline Leporellus vittatus & Anostomidae & $\mathrm{x}$ & & & & & 20 \\
\hline Rhinodoras dorbignyi & Doradidae & $\mathrm{x}$ & & & & & 20 \\
\hline Pseudoplatistoma corruscans & Pimelodidae & $\mathrm{x}$ & & & & & 20 \\
\hline Pinirampus pirinampus & Pimelodidae & $\mathrm{x}$ & & & & & 20 \\
\hline Moenkhausia dichroura & Characidae & $\mathrm{x}$ & & & & & 20 \\
\hline Loricaria vetula & Loricariidae & $\mathrm{x}$ & & & & & 20 \\
\hline Hypostomus regani & Loricariidae & $\mathrm{x}$ & & & & & 20 \\
\hline Cyprinus carpio & Cyprinidae & $\mathrm{x}$ & & & & & 20 \\
\hline Richness & & 39 & 35 & 34 & 23 & 35 & \\
\hline
\end{tabular}

(1) = Torloni et al. (1993); (2) = Castro (1997); (3) = Barrella and Petrere (2003); (4) = Freitas (1999); (5) = Petesse (present study). Sinonimy and taxonomic doubts: $(*)$ : Astyanax bimaculatus $=$ A. aliparanae; Tripotheus sp. $=$ T.a.angulatus in $(1) \mathrm{e}$ (3); . paranensis in (5); Rhamdia sp. = R. quelen in (5); Crenicichla sp. = Crenicichla britskii in (1) e Crenicichla haroldoi in (5); Cichla sp. = Cichla ocellaris in (1) e Cichla monoculus in (4); Leporinus sp. = Leporinus elongatus in (2).

labrosus (Pimelodidae, benthofagous) was not collected in our samples and, finally, in Cichlidae, we observed the appearance of $S$. jurupari. Compared to the Torloni et al. (1993) list, the absence of the most important fishing species (Cyprinus carpio, P. corruscans, P. pirinampu, $R$. dorbignyi) can be observed.

\subsection{Hydraulic management}

Time series analysis shows that most of the water retention time (RT) values are between 40 and 80 days with a maximum of 131 (1971) and a minimum of 25 days (1983); the average is 69 days. The tendency of RT declining with time is shown in Figure 3. The linear regression equation (RT vs. years) shows a significant negative relationship between the two variables. The statistics of interest are: RT $=2486.1-1.22$ year, $n=33$, Pearson correlation coefficient $r=-0.65\left(r^{2}=0.42\right)$ $(\mathrm{p}<0.01)$. The Durbin-Watson index, whose value is close to $2(d=1.94, \mathrm{p}>0.05)$, indicates the absence of autocorrelation, validating the analysis. Note that the reservoir is loosing on average 1.22 days/year in its retention time, which seems quite high.

The reservoir yearly maximum range (YMR) lies between $1.5 \mathrm{~m}$ (1976) and $9.6 \mathrm{~m}$ (1968) with a mean of $5.2 \mathrm{~m}$ (Figure 4). The YMR were higher than $7 \mathrm{~m}$ in 1968, 1969, 1973, 1980, 1999, and 2000. Landscape morphology and profundity measures, show that the reservoir littoral zones have lower slopes and an average

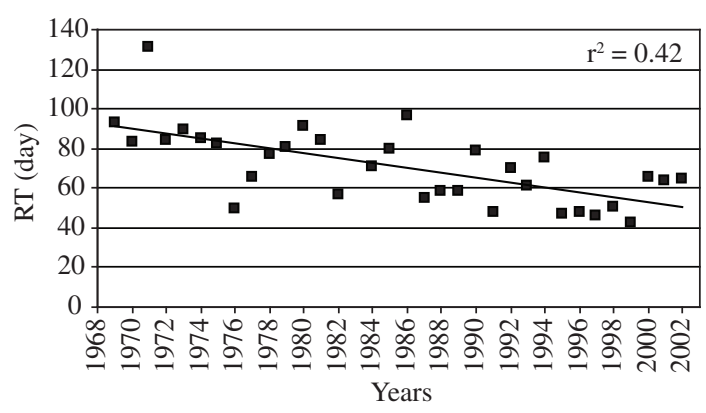

Figure 3. Relationship between RT (retention time) and year from 1969 to 2002. The year of 1983 is not included because it is an outlier. RT $=2486.1-1.22$ year, $n=33$, $r=-0.65\left(\mathrm{r}^{2}=0.42\right)(\mathrm{p}<0.01)$.

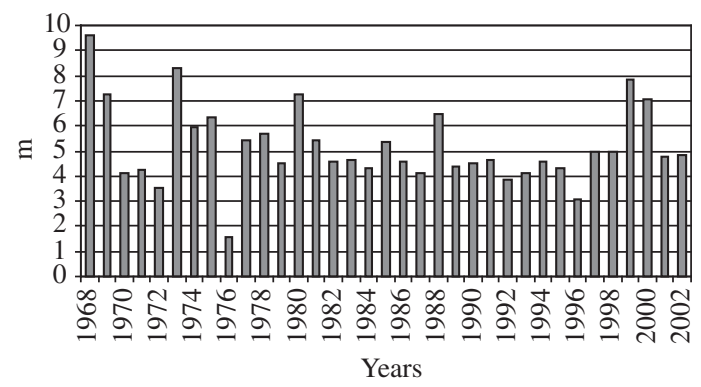

Figure 4. Yearly maximum range (YMR, m) of Barra Bonita Reservoir. 
profundity of $4.5 \mathrm{~m}$, with the exception of the right side of the Piracicaba river zone where a maximum profundity of $9 \mathrm{~m}$ was observed. The minimum depths were in the mouth of a tributary and a lateral station, of 3.2 and $2.5 \mathrm{~m}$, respectively.

The hydraulic cycle of the reservoir is shown in Figure 5. The reservoir flooding phase ranges from December to May and the emptying phase from June to November.

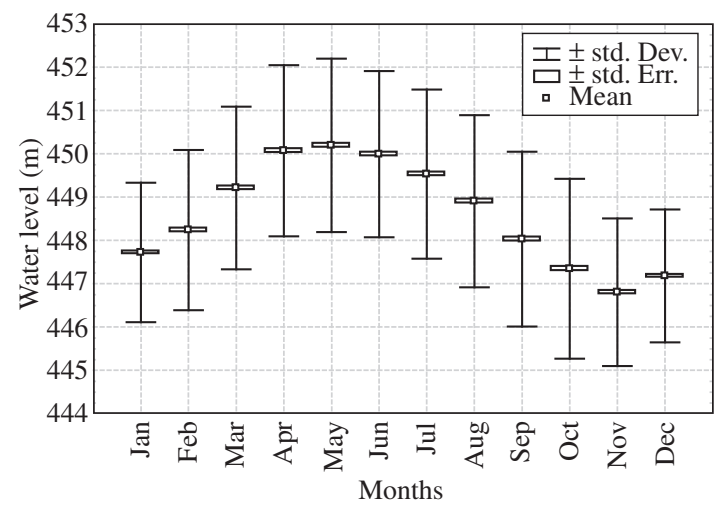

Figure 5. Monthly mean water level of Barra Bonita reservoir, from 1969 to 2002.

\subsection{Species richness - jackknife estimate}

The number of species estimated with the jackknife method was 38 . The confidence limit $(95 \%)$ pointed out a minimum of 34.6 and a maximum of 41.2 species.

\subsection{The trophic structure}

Figure 6 shows the trophic category structure of the present fish community in the Barra Bonita Reservoir. The widest category is the omnivorous that covers $40 \%$ (14) of the species. The second one is the carnivorous with $17 \%$ (6), followed by the iliophagous and insectivorous,

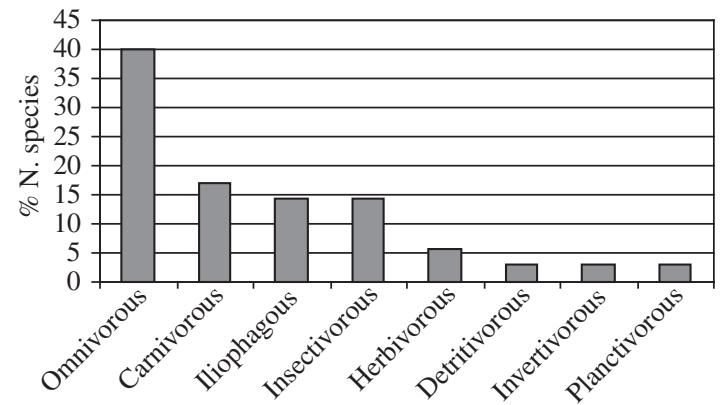

Figure 6. Trophic structure of the fish community of Barra Bonita Reservoir.

Table 2. Trophic categories. Number in parentheses after a species name corresponds to bibliography reference.

\begin{tabular}{|c|c|c|}
\hline Trophic category & Species & Authors \\
\hline \multirow[t]{6}{*}{ Omnivorous } & $\begin{array}{l}\text { S. jurupari (1), A. fasciatus (2), } \\
\text { M. maculatus (3), S. intermedius (4), } \\
\text { S. fasciatus (5), S.nasutus (6) }\end{array}$ & $\begin{array}{l}\text { 1) Fishbase (2004); Smith et al. (2003); 2) Lopes } \\
\text { (1997); 3) Smith et al. (2003); Nomura (1984); } \\
\text { 4) Celi-Fedatto-Abelha et al. (2001); 5) Fishbase } \\
\text { (2004); 6) Nomura (1984); }\end{array}$ \\
\hline & $\begin{array}{l}\text { R. quelen (7), P. maculatus (8), } \\
\text { A. altiparanae (9) }\end{array}$ & $\begin{array}{l}\text { 7) Nakatani (2001); Nomura (1984); Smith et al. } \\
\text { (2003); Hahn et al. (1997); 8) Hahn et al (1997); } \\
\text { Agostinho et al. (1997); Lima (2000); Araújo (1998); } \\
\text { 9) Costa and Braga (1993); }\end{array}$ \\
\hline & G. brasiliensis (10) & 10) Lopes (1997); Araújo (1998) \\
\hline & A. schubarti (11) & 11) Costa and Braga (1993); Lopes (1997); \\
\hline & L. obtusidens (12), L. lacustris (13) & $\begin{array}{l}\text { 12) Hahn et al. (1997); Nomura (1984); } \\
\text { 13) Hahn et al. (1997); Fishbase (2004); Smith } \\
\text { et al. (2003); }\end{array}$ \\
\hline & O. niloticus (14) & 14) Nakatani (2001); \\
\hline Herbivorous & $\begin{array}{l}\text { P. mesopotamicus (15); H. ancistroides } \\
\text { (22) }\end{array}$ & $\begin{array}{l}\text { 15) Hahn et al. (1997); Fishbase (2004); 22) Hahn } \\
\text { et al. (1997); Nomura (1984); }\end{array}$ \\
\hline Iliophagous & $\begin{array}{l}\text { P. lineatus (16), S. insculpta (17), } \\
\text { C. modestus (18), C. nagelii (19); } \\
\text { A. piracicabae (20) }\end{array}$ & $\begin{array}{l}\text { 16) Hahn et al. (1997); 17) Hahn et al. (1997); } \\
\text { 18) Hahn et al. (1997); Nomura and Taveira (1979); } \\
\text { 19) Hahn et al. (1997); 20) Hahn et al. (1997); }\end{array}$ \\
\hline Detritivorous & L. anisitsi (21), & 21) Hahn et al. (1997); \\
\hline Invertivorous & H. littorale (23) & 23) Hahn et al. (1997); Signorini (1999); \\
\hline Insectivorous & $\begin{array}{l}\text { G. carapo (24), Crenicichla sp. (25)., } \\
\text { Pimelodella sp.(26), H. eques (27), } \\
\text { T. paranensis (28) }\end{array}$ & $\begin{array}{l}\text { 24) Carneiro (1998); Hahn et al. (1997); 25) Hahn } \\
\text { et al. (1997); 26) Hahn et al. (1997); 27) Nomura } \\
\text { (1984) 28) Nakatani (2001); }\end{array}$ \\
\hline Planktivorous & M. intermedia (29) & 29) Costa and Braga (1993); \\
\hline Carnivorous & $\begin{array}{l}\text { P.squamosissimus (30), A. lacustris (31), } \\
\text { S. spilopleura (32), S. maculatus (33), } \\
\text { S. hilarii (34), H. malabaricus (35) }\end{array}$ & $\begin{array}{l}\text { 30) Braga (1998); Smith et al (2003); 31) Hahn et al. } \\
\text { (1997); 32) Hahn et al. (1997); Nomura (1984); } \\
\text { 33) Fishbase (2004); 34) Nomura (1984); 35) Hahn } \\
\text { et al. (1997). }\end{array}$ \\
\hline
\end{tabular}


both with $14 \%$ (5). The detritivorous, invertivorous, and planktivorous categories, which are known as species with high specialized diet, are least represented (Table 2).

\subsection{The reproductive structure}

This information is available for $80 \%$ of the species we sampled. The analyses of the reproductive structure, shows that the reproductive period spans from September/ October to March/April. Figure 7 shows the frequency in number and weight of the 15 most abundant species in our samples by type of reproduction. It can be observed that the partial reproduction strategy is the most common and only two species, L. obtusidens and Liposarcus anisitsi, have total spawning. Of those, L. obtusidens undertakes spawning migrations and L. anisitsi exhibits parental care.

Taking into account the reproductive strategies, we observed that $31 \%$ of the species belongs to the "nonmigratory without parental care" category. The migratory and the parental care category are also well represented by respectively with 26 and $23 \%$ of the species. Regarding the resilience, the medium category is the most common with $46 \%$ of the species. Only two species, Hoplias malabaricus and L. anisitsi, belong to the low category and, therefore, can be considered "vulnerable". On the other hand, $31 \%$ of species show high resilience. The resilience information is not available for $17 \%$ of the species sampled.

The overlap between the reservoir hydraulic cycle (emptying and flooding periods throughout the year)

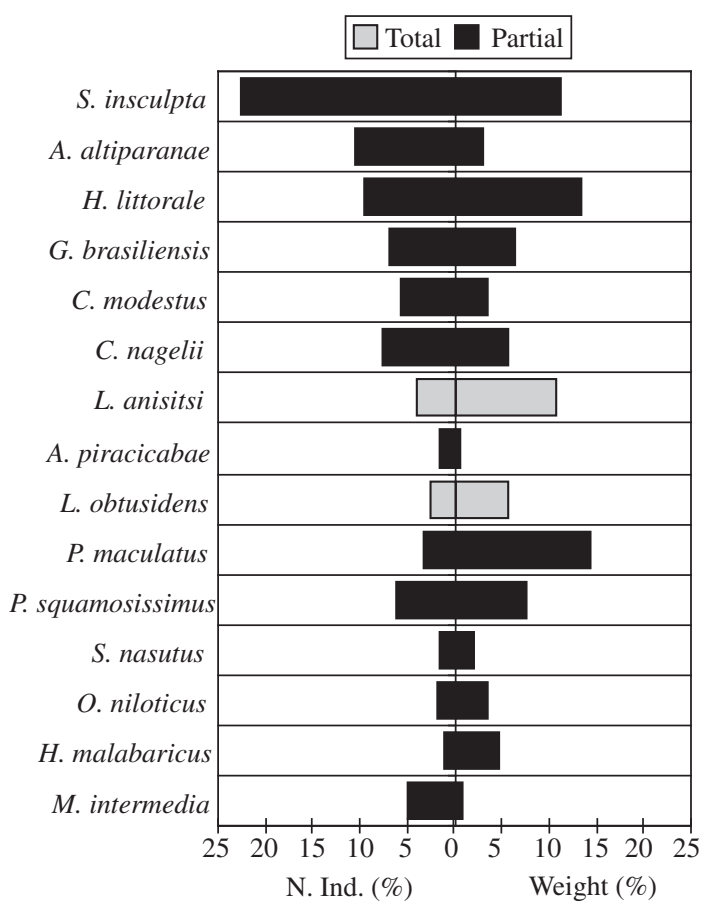

Figure 7. Frequency in number and weight of the most abundant species and its reproductive strategy, total and partial spawning. with the fish reproductive period shows that most species spawn from September to March (Table 3). The period of September/November corresponds to the final emptying period when the reservoir water level reaches its minimum. Figure 8 shows the daily reservoir level fluctuation from January 1997 to December 2002. From this it can be observed that the period from December to May (flooding period), differently from the steady nature of the emptying period, is characterized by unpredictable micro-pulses (short-term high and low water levels fluctuations), caused by the frequency and intensity of summer rains.

\section{Discussion}

The number of species we sampled (35) is included in the confidence interval of the Jakknife estimate. Thus, we can infer that the species richness is not overestimated (Krebs, 1998) and the sampling method applied was appropriate. This is also reinforced by the other lists in which all but one showed richness in the estimated range. The lowest number of species registered by Freitas (1999) can be explained considering that he sampled only the reservoir lentic zone.

The present fish community at Barra Bonita Reservoir is constituted mainly of species with mediumhigh resilience that seem adapted to the degraded conditions and environmental stress. Granado-Lorencio (1991) shows that in an unstable environment like that of reservoirs, fish communities do not depend upon the availability of food resources, but they are the result of their own biology emphasizing the importance of special reproductive strategy likes partial spawning, parental care and migration in the performance of a species.

The temporal changes observed in the Barra Bonita Reservoir fish community in the last 15 years, can be related to natural causes and/or environmental aging. The first is related to the community resilience and to the capacity of each species to respond to environmental alterations. Aging, on the other hand, is the result of a natural process that in reservoirs is much faster than in natural lacustrine habitat. Aging is still poorly studied, because most reservoirs are still "young" and because frequently there are no data on fish community previous to dam closure (Agostinho et al.,1999), which is the case of Barra Bonita Reservoir.

Regarding the events resulted from the aging process, Fernando and Holcik (1991) claim that the ichthyofauna of reservoirs, at the first instance, results from the riverine speciespre-adaptedtolacustrineconditions. Subsequently, a population depletion is noticed which affects mainly the large-sized fish, usually migratory, of long life, and with low reproductive potential ( $\mathrm{k}$-strategists) species. On the contrary, the species whose food availability is high and that are small-sized, sedentary, of short life and with high reproductive potential (r-strategists), become dominant in the reservoir (Agostinho, 1995; Agostinho et al., 1999; Lowe-McConnel, 1999). According to Agostinho et al. 
Table 3. Overlap between the reproductive period and the hydraulic cycle of Barra Bonita Reservoir.

\begin{tabular}{|c|c|c|c|c|c|c|c|c|c|c|c|c|}
\hline $\begin{array}{c}\text { Hydraulic cycle of } \\
\text { Barra Bonita Reservoir }\end{array}$ & & & & & & & & & & & & \\
\hline Species & Jun. & Jul. & Aug. & Sep. & Oct. & Nov. & Dec. & Jan. & Feb. & Mar. & Apr. & May. \\
\hline Leporinus lacustris & & & $\mathrm{x}$ & $\mathrm{x}$ & $\mathrm{x}$ & $\mathrm{x}$ & $\mathrm{x}$ & $\mathrm{x}$ & $\mathrm{x}$ & & & \\
\hline Leporinus obtusidens & & & & & $\mathrm{x}$ & $\mathrm{x}$ & $\mathrm{x}$ & $\mathrm{x}$ & $\mathrm{x}$ & & & \\
\hline Schizodon intermedius & & & & & & $\mathrm{x}$ & $\mathrm{x}$ & & & & & \\
\hline Schizodon fasciatus & & & & & $\mathrm{x}$ & $\mathrm{x}$ & $\mathrm{x}$ & $\mathrm{x}$ & $\mathrm{x}$ & $\mathrm{x}$ & & \\
\hline Schizodon nasutus & & & & & & $\mathrm{x}$ & $\mathrm{x}$ & $\mathrm{x}$ & & & & \\
\hline Acestrorhynchus lacustris & & & & $\mathrm{x}$ & $\mathrm{x}$ & $\mathrm{x}$ & $\mathrm{x}$ & $\mathrm{x}$ & $\mathrm{x}$ & $\mathrm{x}$ & & \\
\hline Astyanax altiparanae & $\mathrm{x}$ & $\mathrm{x}$ & & & & $\mathrm{x}$ & $\mathrm{x}$ & $\mathrm{x}$ & $\mathrm{x}$ & $\mathrm{x}$ & $\mathrm{x}$ & $\mathrm{x}$ \\
\hline Astyanax fasciatus & & & & $\mathrm{x}$ & $\mathrm{x}$ & $\mathrm{x}$ & $\mathrm{x}$ & $\mathrm{x}$ & $\mathrm{x}$ & & & \\
\hline Astyanax schubarti & & & & & & & $\mathrm{x}$ & $\mathrm{x}$ & $\mathrm{x}$ & $\mathrm{x}$ & $\mathrm{x}$ & $\mathrm{x}$ \\
\hline Moenkhausia intermedia & & & & & $\mathrm{x}$ & $\mathrm{x}$ & $\mathrm{x}$ & $\mathrm{x}$ & $\mathrm{x}$ & $\mathrm{x}$ & & \\
\hline Salminus hilari & & & & & $\mathrm{x}$ & $\mathrm{x}$ & $\mathrm{x}$ & $\mathrm{x}$ & $\mathrm{x}$ & & & \\
\hline Triportheus paranensis & & & & & & & & & & & & \\
\hline Hyphessobrycon eques & & & & & & & & & & & & \\
\hline Piaractus mesopotamicus & & & & & & $\mathrm{x}$ & $\mathrm{x}$ & $\mathrm{x}$ & & & & \\
\hline Serrasalmus maculatus & & & & & & & & & & & & \\
\hline Serrasalmus spilopleura & & & & & $\mathrm{x}$ & $\mathrm{x}$ & $\mathrm{x}$ & $\mathrm{x}$ & $\mathrm{x}$ & $\mathrm{x}$ & $\mathrm{x}$ & \\
\hline Metymnis maculatus & & & & & & & & & & & & \\
\hline Cyphocharax modestus & & & $\mathrm{x}$ & $\mathrm{x}$ & $\mathrm{x}$ & $\mathrm{x}$ & $\mathrm{x}$ & $\mathrm{x}$ & $\mathrm{x}$ & $\mathrm{x}$ & $\mathrm{x}$ & $\mathrm{x}$ \\
\hline Cyphocharax nagelii & & & & & $\mathrm{x}$ & $\mathrm{x}$ & $\mathrm{x}$ & $\mathrm{x}$ & $\mathrm{x}$ & & & \\
\hline Steindachnerina insculpta & & & $\mathrm{x}$ & $\mathrm{x}$ & $\mathrm{x}$ & $\mathrm{x}$ & $\mathrm{x}$ & $\mathrm{x}$ & $\mathrm{x}$ & $\mathrm{x}$ & $\mathrm{x}$ & \\
\hline Hoplias malabaricus & & & & $\mathrm{x}$ & $\mathrm{x}$ & $\mathrm{x}$ & $\mathrm{x}$ & $\mathrm{x}$ & $\mathrm{x}$ & & & \\
\hline Apareidon piracicabae & & & & $\mathrm{x}$ & $\mathrm{x}$ & $\mathrm{x}$ & $\mathrm{x}$ & & & & & \\
\hline Prochilodus lineatus & & & & & & $\mathrm{x}$ & $\mathrm{x}$ & $\mathrm{x}$ & $\mathrm{x}$ & & & \\
\hline Hoplosternum littorale & & & & & & $\mathrm{x}$ & $\mathrm{x}$ & $\mathrm{x}$ & $\mathrm{x}$ & $\mathrm{x}$ & $\mathrm{x}$ & \\
\hline Liposarcus anisitsi & & & & & & $\mathrm{x}$ & $\mathrm{x}$ & & & & & \\
\hline Hypostomus ancistroides & & & & $\mathrm{x}$ & $\mathrm{x}$ & $\mathrm{x}$ & & & & & & \\
\hline Pimelodus maculatus & & & & & $\mathrm{x}$ & $\mathrm{x}$ & $\mathrm{x}$ & $\mathrm{x}$ & $\mathrm{x}$ & $\mathrm{x}$ & & \\
\hline Pimelodella sp. & & & & & & & & & & & & \\
\hline Rhamdia quelen & & & & & & & & & & & & \\
\hline Gymnotus carapo & & & & & $\mathrm{x}$ & $\mathrm{x}$ & $\mathrm{x}$ & $\mathrm{x}$ & $\mathrm{x}$ & & & \\
\hline Crenicichla haroldoi & & & & & & & & & & & & \\
\hline Geophagus brasiliensis & & & & $\mathrm{x}$ & $\mathrm{x}$ & $\mathrm{x}$ & $\mathrm{x}$ & $\mathrm{x}$ & $\mathrm{x}$ & & & \\
\hline Satanoperca jurupari & & & & & & & & & & & & \\
\hline Oreochromys niloticus & & & & $\mathrm{x}$ & $\mathrm{x}$ & $\mathrm{x}$ & & & & & & \\
\hline Plagioscion squamosissimus & & & & & & $\mathrm{x}$ & $\mathrm{x}$ & $\mathrm{x}$ & $\mathrm{x}$ & & & \\
\hline
\end{tabular}

\begin{tabular}{|c|c|c|}
\hline Flooding & Empty & Period when most species spawn \\
\hline
\end{tabular}

(1999), the increase also of species with parental care is an index of environmental aging.

With regard to Neotropical reservoirs, Agostinho et al. (1999) highlights several events, the main points of which are summarized in Table 4. It is clear that the largest changes in Barra Bonita Reservoir may have happened
40 years ago, during the reservoir filling phase. The absence of surveys in the area before and after the filling phase, do not allow us a complete analysis of the changes that took place. However, considering the predominance of opportunistic (omnivorous and iliophagous) versus specialist (herbivorous/planktivorous) categories, 


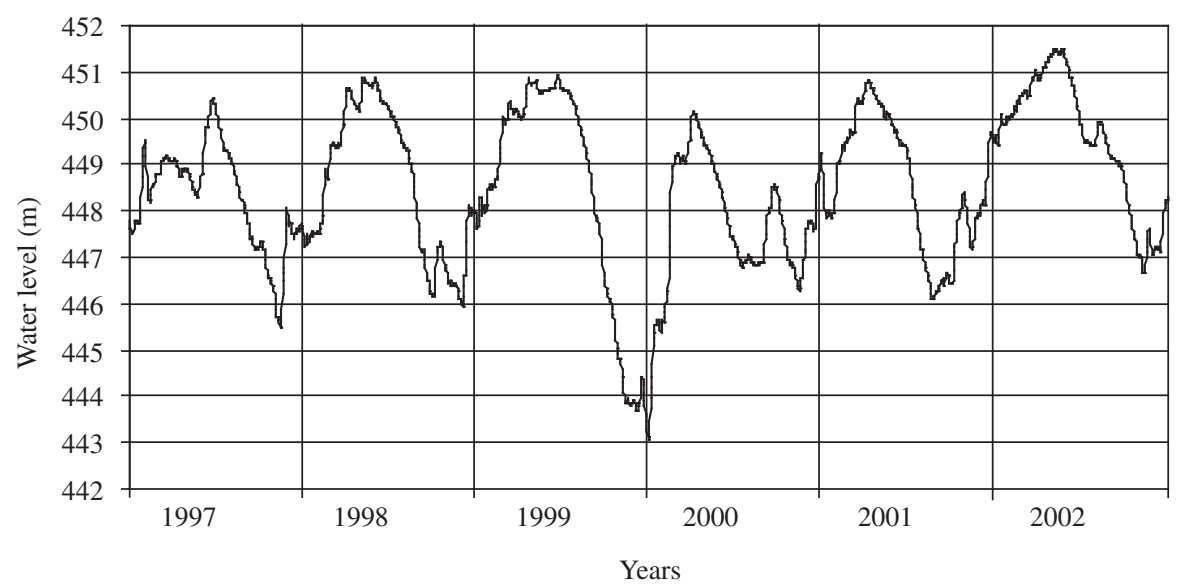

Figure 8. Daily water level (m) of Barra Bonita Reservoir from January 1997 to December 2002.

Table 4. Aging process in reservoirs (adapted from Agostinho et al., 1999).

\begin{tabular}{|c|c|c|c|}
\hline & Closing stage & Colonization stage & Aging stage \\
\hline Definition & $\begin{array}{l}\text { The period between } \\
\text { the reservoir's closing } \\
\text { and ordinary operating } \\
\text { conditions. Usually it is } \\
\text { between } 8-80 \text { days. }\end{array}$ & $\begin{array}{l}\text { From the end of the closing stage to aging } \\
\text { signs. }\end{array}$ & $\begin{array}{l}\text { The period characterized } \\
\text { by strong environmental } \\
\text { degradation and } \\
\text { simplification of living } \\
\text { communities. }\end{array}$ \\
\hline $\begin{array}{l}\text { Abiotic } \\
\text { environment }\end{array}$ & $\begin{array}{l}\text { Increase of retention } \\
\text { time, increase of nutrient } \\
\text { concentration, presence } \\
\text { of anoxia and thermal } \\
\text { stratification, increase of } \\
\text { transparence (by suspended } \\
\text { sedimentation particles), } \\
\text { turbulence reduction. }\end{array}$ & $\begin{array}{l}\text { The abiotic features are strongly related to } \\
\text { input water quality and to the reservoir's } \\
\text { hydraulic management. The range of } \\
\text { fluctuation level affects the environmental } \\
\text { general productivity. }\end{array}$ & $\begin{array}{l}\text { Nutrient accumulation, } \\
\text { sedimentation, habitat } \\
\text { deterioration, particularly } \\
\text { of the littoral zone. }\end{array}$ \\
\hline $\begin{array}{l}\text { Biotic } \\
\text { environment }\end{array}$ & Phytoplankton increase & $\begin{array}{l}\text { Macrophytes' gradual } \\
\text { increase. Phytoplankton increase }\end{array}$ & $\begin{array}{l}\text { Phytoplankton increases } \\
\text { with evidence of negative } \\
\text { effect of eutrophization; } \\
\text { reduction of benthonic } \\
\text { organisms. }\end{array}$ \\
\hline Fish & $\begin{array}{l}\text { Two phases: } \\
\text { 1. Fast river species } \\
\text { diffusion in the reservoir, } \\
\text { independent of colony } \\
\text { habitat type during the } \\
\text { river phase. High capture } \\
\text { rate. } \\
\text { 2. Moving to the littoral } \\
\text { reservoir areas and in } \\
\text { tributary mouth by the } \\
\text { formation of anoxic } \\
\text { strata. }\end{array}$ & $\begin{array}{l}\text { - High production and diversity in littoral } \\
\text { reservoir area; absence of pre-adapted } \\
\text { species to colonization of pelagic } \\
\text { zone (these organisms require special } \\
\text { morphological and behavior adaptations } \\
\text { to feed, to reproduce, to move, and to } \\
\text { avoid predators). } \\
\text { - The community is dominated by sedentary } \\
\text { and medium-size species. } \\
\text { - The diet is constituted mainly of material } \\
\text { of autochthonous origin. In general, } \\
\text { detritivorous and iliophagous species } \\
\text { reduced. On the other hand, herbivorous } \\
\text { and zooplanktivorous increase. } \\
\text { The littoral zone is colonized by generalist } \\
\text { species and with broad habitat tolerance } \\
\text { changes. } \\
\text { Reduction of migratory species } \\
\text { importance (mainly big migrators); } \\
\text { Increase of species with parental care, and } \\
\text { more elaborated reproductive strategies. }\end{array}$ & $\begin{array}{l}\text { - Reduction of } \\
\text { predators. } \\
\text { Increase of small-size } \\
\text { and opportunistic } \\
\text { species. } \\
\text { - Increase of short } \\
\text { life cycle species, } \\
\text { fast growth and } \\
\text { reproductive } \\
\text { compensation. } \\
\text { Dominance of adapted } \\
\text { species to high } \\
\text { turbidity conditions, } \\
\text { and low oxygen } \\
\text { concentration. }\end{array}$ \\
\hline
\end{tabular}


the predominance of small-sized species with high reproductive compensation, fast growth and welladapted to environmental variability, the reservoir can be placed in a intermediate phase between colonization and aging. This explains, also, the absence of most Anostomidae species in the surveys of the 90's. In spite of the fact that in the last 15 years, a general stability in species richness has been observed, an alteration in relation to fish composition is evident, showing that the dynamic of the community is faster in this environment. In particular, it is evidenced by the dominance of omnivorous and iliophagous, and the disappearance of medium-large migrators. (R. dorbignyi, S. maxillosus and $P$. corruscans). This last observation just confirms the dam impact on migratory species.

The hydraulic management of Barra Bonita Reservoir reveals the declining of retention time and the YMR over the considered reasonable range of 2.5 - $4 \mathrm{~m}$ (Jackson and Marmulla, 2000). These observations suggest a decrease in the reservoir storage capacity and the sensitivity of the shallow areas in the lateral and mouth of tributary habitats to the bottom exposure. This limits the spawning areas in the reservoir and affects juveniles by the loss of food resources and sheltering.

According to Vazzoler and Menezes (1992) the increase of temperature and the beginning of flooding period give the starting signal for reproduction of the Characiformes in the Paraná River basin. The anthropogenic management of Barra Bonita Reservoir shows a flooding phase from December to May and an emptying phase from June to November. The alteration of the natural hydrological cycle affects the fish community composition because it is evident that only those species with partial reproductive strategy and parental care are best succeeded in the reservoir.

On the basis of our results, we are led to conclude that Barra Bonita reservoir is getting into an aging stage, reinforced by the water eutrophy conditions (Barbosa et al., 1999). In this context, constant environmental monitoring becomes necessary and fish can be considered a good indicator of this, because they summarize the negative effects of environmental degradation that also affect other ecosystem sectors (Fausch et al., 1990). At the same time, they are an important resource not only from a natural-ecological point of view, but also from a social and economical perspective.

Acknowledgments - We thank CNPq, and UNESP for partial financial support. We also thank APTA, Instituto de Pesca and MZUSP, for the facilities and fish identification.

\section{References}

AGOSTINHO, AA., 1995. Considerações sobre a atuação do setor elétrico na preservação da fauna aquática e dos recursos pesqueiros, p. 8-19 In Comitê Coordenador das Atividades de Meio Ambiente - COMASE (ed.), Seminário sobre Fauna Aquática e o Setor Elétrico Brasileiro, Eletrobrás, Rio de Janeiro, Caderno 4, 104p.
AGOSTINHO, AA., FERREIRA, HJ., GOMES, LC., BINI, LM. and AGOSTINHO, CS., 1997. Composição abundancia e distribuição espaço-temporal da ictiofauna, p. 179-208 In VAZZOLER, AEA. de M., AGOSTINHO, ÂA., SEGATTI HAHN, N. (eds.), A Planície de Inundação do Alto rio Paraná, Editoria da Universidade Estadual de Maringá, Nupélia, Maringá, 460p.

AGOstinho, AA., JULIO, HF. and PETRERE-JR, M., 1994. Itaipu reservoir (Brasil): impact of the impoundment on the fish fauna and fisheries, p. 171-184. In COWX, IG. (ed.), Rehabilitation of Freshwater Fisheries., Fishing News Books, $485 \mathrm{p}$.

AGOSTINHO, AA., MIRANDA, LE., BINI, LM., GOMES, LC., THOMAZ, SM. and SUZUKI, HI., 1999. Patterns of colonization in Neotropical reservoirs and prognoses on aging. p. 227-265. In TUNDISI, JG. and STRASKRABA, M. (eds.), Theoretical Reservoir Ecology and its Applications, Backhuys Publishers, Leiden, 585 p.

ARAUJO, FG., 1998. Adaptação do Índice de integridade biótica usando a comunidade de peixes para o rio Paraíba do Sul. Rev. Brasil. Biol., vol. 58, no. 4, p. 547-558.

BARBOSA, FAR., PADISAK, J., ESPINDOLA, ELG., BORICS, G. and ROCHA, O., 1999. The cascading reservoir continuum concept (CRCC) and its application to the river TietêBasin, São Paulo State, Brasil, p. 425-437. In TUNDISI, JG. and STRASKRABA, M. (eds.), Theoretical Reservoir Ecology and its applications, Backhuys Publishers, Leiden., 585 p.

BARRELlA, W. and PETRERE-JR, M., 2003. Fish community alterations due to pollution and damming in Tietê and Paranapanema rivers (Brazil). River Res. Applic.,vol. 19, p. 59-76.

BERGKAMP, G., McCARTNEY, M., DUGAN, P., McNEELY, J. and ACREMAN, M., 2000. Dams, ecosystem functions and environmental restoration. WCD Thematic review Environmental Issues II.1, World Commission on dams (WCD). Website: http://www.dams.org

BRAGA, FMS., 1997. Biologia reprodutiva de P. squamosissimus (Teleostei, Scianidae) na represa de Barra Bonita, Rio Piracicaba (SP). Revista UNIMAR, vol. 19, no. 2, p. 447-460.

-, 1998. Alimentação de Plagioscion squamosissimus (Osteichthys, Scianidae) no reservatório de Barra Bonita, Estado de São Paulo. Iheringia Ser. Zool., no. 84, p. 11-19.

-, 1999. Idade, crescimento e taxas de mortalidade de A. bimaculatus (Characidae, Tetragonopterinae) na Represa de Barra Bonita (SP). Naturalia, vol. 24, p. 239-250.

BRAGA, FMS. and GENNARI-FL, O., 1991. Estudos sobre a fecundidade, desova e mortalidade natural de M.intermedia (Characidae, Tetragonopterinae) na represa de Barra Bonita, Rio Piracicaba, SP. Naturalia, v. 16, p. 55-68.

BRANCO, SM. and ROCHA, AA., 1977. Poluição, proteção e usos múltiplos de represas. CETESB, Editora Edgar Blucher, São Paulo, 185p.

BRITSKI, HA., 1994. A fauna de peixes brasileiros de água doce e o represamento de rios, p. 23-30. In Comitê Coordenador das Atividades de Meio Ambiente - COMASE (ed.), Seminário sobre fauna aquática e o setor elétrico brasileiro. Caderno 1, 61p., Eletrobrás, Rio de Janeiro.

CARNEIRO, SC., 1998. Alimentação da Tuvira, Gymnotus "aff" carapo em duas represas do Estado de São Pulo 
(Osteichthyes, Gymnotidae). Master Dissertation em Ciências Biológicas (Área Zoologia), Universidade Estadual Paulista, Rio Claro, 87 p.

CASTRO, ACL., 1997. Aspectos ecológicos da comunidade ictiofaunística do reservatório de Barra Bonita, SP. Rev. Brasil. Biol., vol. 57, no. 4, p. 665-676.

CASTRO, RM. and ARCIFA, MS., 1987. Comunidades de peixes de reservatórios no sul do Brasil. Rev. Brasil. Biol., vol. 47 , no. 4 , p. 493-500.

CELI-FEDATTO-ABELHA, M., AGOSTINHO, AA. and GOULART, E., 2001. Plasticidade trófica em peixes de água doce. Acta Scientiarum, vol. 23, no. 2, p. 425-434.

CESP, 1996. Santa Maria da Serra Empreendimento hídrico. Relatório ambiental preliminar. CESP (Companhia Energética de São Paulo). Maio, 1996.

CHATTERJEE, S. and PRICE, B., 1991. Regression Analysis by Example. John Wiley and Sons, Inc., 278p.

COSTA, FE. and BRAGA, FMS., 1993. Estudo da alimentação natural de A. bimaculatus, A. schubarti e $M$. intermedia (Characidae, Tetragonopterinae) na represa de Barra Bonita, rio Piracicaba (SP). Revista UNIMAR, vol. 15, no. 2, p. 117-134.

CRAIG, JF., 2000. Large dams and freshwater fish biodiversity. Contributing paper. Prepared for Thematic Review II.1: Dams, ecosystem functions and environmental restoration. World Commission on dams (WCD). Website: http://www.dams.org

DAJOZ, R., 1973. Ecologia geral. Editoria da Universidade de São Paulo, Editoria Vozes Limitada, 471 p.

DE BERNARDI, R. and GIUSSANI, G., 1993. Biomanipolazione dei corpi idrici. In MARCHETTI, R. (ed.), Ecologia applicata. 1055p., Cittá Studi, Milano.

DRAPER, NR. and SMITH, H., 1966, Applie Regression Analysis. John Wiley and Sons, Inc., 709p.

FAUSCH, KD., LYONS, J., KARR, JR. and ANGERMEIR, PL., 1990. Fish communities as indicators of environmental degradation. American Fisheries Society Symposium, vol. 8, p. $123-144$

FERNANDO, CH. and HOLCIK, J., 1991. Fish in reservoir. Int. Revue Ges. Hydrobiol., vol. 76, p. 149-167.

FISHBASE, 2004. www.fishbase.org., ICLARM. [Acesso 12/2004].

FREITAS, EC., 1999. O efeito de recifes artificiais sobre as associações de peixes do Rio Tietê, na área de influência do Reservatório de Barra Bonita (Estado de São Paulo - Brasil). PhD Thesis, EESC - USP - Escola de Engenharia de São Carlos da Universidade de São Paulo,133p.

GENNARI-FL, O. and BRAGA, FMS., 1996. Fecundidade e desova de A. bimaculatus e A. schubarti (Characidae, Tetragonopterinae) na represa de Barra Bonita, Rio Piracicaba (SP). Revista UNIMAR, vol. 18, no. 2, p. 241-254.

GRANADO-LORENCIO, C., 1991. Fish communities of Spanish reservoir system: a non-deterministic approach. Verh. Internat. Verein. Limnol., vol. 24, p. 2428-2431.

-, 1992. Fish species ecology in Spanish freshwater ecosystems. Limnetica, vol. 8, p. 255-261.

HAHN, N., ANDRIAN, I., FUGI, R. and ALMEIDA, VL., 1997. Ecologia trófica. In VAZZOLER, AEA. de M., AGOSTINHO,
ÂA., SEGATTI HAHN, N. (eds.), A Planície de Inundação do Alto rio Paraná, Editoria da Universidade Estadual de Maringá, Nupélia, Maringá, 460p.

JACKSON, D. and MARMULLA, G., 2000. The influence of dams on river fisheries. Contributing paper. Prepared for Thematic Review II.1: Dams, ecosystem functions and environmental restoration. World Commission on dams (WCD). Website: http://www.dams.org

JENNING, MJ., FORE, LS., and KARR JR., 1995. Biological monitoring of fish assemblages in Tennessee Valley reservoirs. Regulated rivers: Research and Management, vol. 11, p. $263-274$

JÚLIO-JR HF., BONECKER, CC. and AGOSTINHO, AA., 1997. Reservatório de Segredo e sua inserção na bacia do rio Iguaçu, 1-18p. In AGOSTINHO, AA., and GOMES, LC. (eds.), Reservatório de Segredo: bases ecológicas para o manejo, Editoria da Universidade Estadual de Maringá, Nupélia, Maringá. 372p.

KARR, JR., 1981. Assessment of biotic integrity using fish communities. Fisheries, vol. 6, no. 6, p. 21-27

KREBS, CJ., 1998. Ecological methodology. Second edition. Benjamin/Cummings CA., 652p.

LARINIER, M., 2000. Dams and fish migration. Contributing paper. Prepared for Thematic Review II.1: Dams, ecosystem functions and environmental restoration. World Commission on dams (WCD). Website: http://www.dams.org

LIMA-JR, SE., 2000. Dieta e condição de Pimelodus maculatus (Osteichthyes, Pimelodidae) nos rios Piracicaba e Mogi-Guaçu, SP. Master Dissertation in Ciências Biológicas (Área Zoologia), Universidade Estadual Paulista, Rio Claro, 152p.

LOPES, FRF., 1997. Análise do conteúdo estomacal e aspectos da anatomia externa e do trato digestivo de peixes da represa do Lobo, Itirapina, SP. Baccalaureate Monograph in Ciências Biológicas, UNESP - Universidade Estadual Paulista, Rio Claro, 43p.,

LOWE-McCONNEL, RH., 1999. Estudosecológicos de comunidades de peixes tropicais. São Paulo-EdUsp, 534p.

MAGELA THOMAZ, S., DO CARMO, RM. and BINI, LM., 1997. Caracterização limnológica dos ambientes aquáticos e influência dos níveis fluviométricos. In VAZZOLER, AEA. de M., AGOSTINHO, ÂA., SEGATTI HAHN, N. (eds.), A Planície de Inundação do Alto Rio Paraná, Editoria da Universidade Estadual de Maringá, Nupélia, Maringá, 460p.

McDONOUGH, TA. and HICKMAN, GD., 1999. Reservoir Fish Assemblage Index development: a tool for assessing ecological health in Tennessee Valley Authority impoundments. In SIMON, TP. (ed.), Assessing the sustainability and Biological Integrity of water resources using fish communities, CRC press, $671 \mathrm{p}$.

McGARIGAL, K., CUSHMAN, S., STAFFORD, S., 2000. Multivariate statistics for wildlife and ecology research. New York, Springer-Verlag, 283p.

MUSICK, JA., 1999. Criteria to define extinction risk in marine fishes. Fisheries, vol. 24, no. 12, p. 6-14.

NAKATANI, K., AGOSTINHO, AA., BAUMGARTNER, G., BIALETZKI, A., SANCHES, PV., MAKRAKIS, M. and PAVANELLI, C., 2001, Ovos e larvas de peixes de água doce: desenvolvimento e manual de identificação. EDUEM, Maringá, 378p. 
NOMURA, H. and TAVEIRA, ACD., 1979. Biologia do sagüiru, Curimatus elegans Steindachner, 1874 do rio Mogi Guaçu, São Paulo (Osteichthyes, Curimatidae). Rev. Brás. Biol., vol. 39, no. 2, p. 331-339

NOMURA, H., 1984. Dicionário dos peixes do Brasil. Editerra Editorial, Brasília, 482p.

OKADA, EK., AGOSTINHO, AA., PETRERE-JR., M. and PENCZAK, T., 2003. Factors affecting fish diversity and abundance in drying ponds and lagoons in the upper Paraná River basin, Brazil. Ecohydrology and Hydobiology, vol. 3, no. 1, p. 97-110.

REIS, RE., KULLANDER, SO. and FERRARIS-JR, CJ., 2003. Check list of the freshwater fishes of South and Central América. EDIPUCRS, Porto Alegre, 742p.,

SANTOS, G., 1980. Estudo da reprodução e hábitos reprodutivos de Schizodon fasciatus, Rhytiodus microlepis e Rhytiodus argenteofuscus (Pices, Anostomidae) do lago Janauacá. Acta Amazônica, vol. 10, no. 2, p. 391-400.

SMITH, W., PEREIRA, CC., ESPINDOLA, EL. and ROCHA, O., 2003. A importância da zona litoral para a disponibilidade de recursos alimentares à comunidade de peixes em reservatórios, p.233-248. In R. Henry (ed.), Ecótonos naslinterfaces dos Ecossistemas Aquáticos, RiMa Editora, 349p.

SIGNORINI, CE., 1999. Alimentação de Hoplosternum littorale Hancock (Callichthyidae, Osteichthyes) do rio Piracicaba e rio Curumbataí, Estado de São Paulo. Master dissertation in Ciências Biológicas (Área Zoologia), Universidade Estadual Paulista, Rio Claro, 113p.,
TORLONI, CE., CORRÊA, A., CARVALHO, A., SANTOS, JJ., GONÇALVES, J., GERETO, E., CRUZ, JA., MOREIRA, JA., SILVA, DC., DEUS, EF. and FERREIRA, A., 1993. Produção pesqueira e composição das capturas em reservatórios sob concessão da CESP nos rios Tietê, Paraná e Grande no período de 1986-1991. Serie: Produção Pesqueira, 001 - CESP, São Paulo, 73p.

TUNDISI, JG., MATSUMURA-TUNDISI, T., 1990. Limnology and eutrophication of Barra Bonita reservoir, São Paulo State, Southern Brazil. Arch. Hydrobiol. Beih. Ergebn. Limnol., n. 33, p. 661-676.

TUNDISI, JG., MATSUMURA-TUNDISI, T. and ROCHA, O., 1999. Theoretical basis for reservoir management, p. 505-528. In TUNDISI, JG. and STRASKRABA, M. (eds.), Theoretical Reservoir Ecology and its applications, Backhuys Publishers, Leiden, $585 \mathrm{p}$.

VAZZOLER, AE. and MENEZES, NA., 1992. Síntese de conhecimentos sobre o comportamento reprodutivo dos Characiformes da América do Sul (Teleostei, Ostariophysi). Ver. Brasil. Biol., vol. 52, no. 4, p. 627-640.

VAZZOLER,AE, SUZUKI, HI., MARQUES, EE. and LIZAMA, M, 1997. Primeira maturação gonadal, períodos e áreas de reprodução. In VAZZOLER, AEA. de M., AGOSTINHO, ÂA., SEGATTI HAHN, N. (eds.), A planície de Inundação do Alto Rio Paraná, Editoria da Universidade Estadual de Maringá, Nupélia, Maringá. 460p.

WOYNAROVICH, E., 1991. The hydroelectric power plants and fish fauna. Verh. Internat. Verein. Limnol., vol. 24, p. 2531-2536. 
